\section{Growth and Flowering Responses of Lupinus varius L. to Paclobutrazol}

\author{
Osman Karaguzel,,${ }^{1,2}$ Ibrahim Baktir, ${ }^{3}$ Sadik Cakmakci, ${ }^{4}$ and \\ Veli Ortacesme ${ }^{2}$ \\ Faculty of Agriculture, Akdeniz University, Campus, Dumlupinar Street, 07070, \\ Antalya, Turkey
}

Additional index words. lupine, growth retardant, triazole

\begin{abstract}
The effects of method of application and dose of paclobutrazol on the growth and flowering characteristics of Lupinus varius L. were studied. On 17 Dec., seeds were sown into $18-\mathrm{cm}$ pots (three seeds per pot) filled with a mixture consisting of 2 peat : 1 river sand (by volume). On 25 Mar., when 5\% of the plants had elongated first internodes, doses of paclobutrazol at 0 (control), $0.625,1.250$, and $2.500 \mathrm{mg}$ a.i./plant were applied to plants as a foliar spray or media drench. The application of paclobutrazol led to a slight shortening of the time to flowering, especially when applied as a foliar spray. Plant height and internode length, length, and internode length of the main inflorescence significantly decreased with increased doses of paclobutrazol and this also happened with the number of branches per plant, branch length, and length and internode length of branch inflorescence. On the contrary, stem, main, and branch inflorescence diameters significantly increased with increased doses of paclobutrazol, whether applied as a foliar spray or media drench. However, drench applications of paclobutrazol were consistently more effective than foliar spray treatments on most of the growth characteristics investigated. Paclobutrazol, in particular when applied as a foliar spray, also increased the number of flowers on main and branch inflorescences relative to the control, but media drenched applications of paclobutrazol at doses of 1.250 and $2.500 \mathrm{mg}$ a.i./plant resulted in consistent significant reductions in the number of flowers on branch inflorescences. Chemical name used: $( \pm)-\left(\mathbf{R}^{*}, \mathbf{R}^{*}\right)-\beta[(4-$ chlorophenyl $)$ methyl $]-\alpha-(1,1-d i m e t h y l)-1 H-1,2,4-$ triazole-1-ethanol (paclobutrazol).
\end{abstract}

The Lupinus L. genus has about 200 species of annuals, perennials, and semi-evergreen and evergreen subshrubs or shrubs, mostly from the Mediterranean, North Africa, and North, Central and South America (Brickell and Zuk, 1997). Lupinus varius L., a short to medium height softly-hairy plant, is one of the annual lupines native to the Mediterranean basin (Blamey and Grey-Wilson, 1998) and South Anatolia (Chamberlain, 1965). The plant has potential for use in landscaping and as a specialty cut-flower crop, possessing an attractive silk-like texture (Burnie, 2000) and a blue flower that is larger than that of related species, such as Lupinus micranthus Guss. or Lupinus luteus L. (Blamey and Grey-Wilson, 1998). In 1989, during landscape surveys of the Gazipasa district (Antalya, Turkey), a native population of Lupinus varius was observed with taller plant height, longer main and branch inflorescences, and higher flower numbers relative to populations of Lupinus varius described

Received for publication 13 Sept. 2003. Accepted for publication 9 May 2004. We gratefully acknowledge James E. Barrett and George Wulster for their critical reading of this manuscript. This research was supported by the Scientific and Technical Research Council of Turkey (Project no. TARP-1814) and the Administration Unit of Scientific Research Projects of Akdeniz University.

${ }^{1}$ To whom reprint requests should be addressed; e-mail okaraguzel@akdeniz.edu.tr.

${ }^{2}$ Associate professor, Department of Landscape Architecture.

${ }^{3}$ Professor, Department of Horticulture.

${ }^{4}$ Professor, Department of Field Crops. previously for South Anatolia by Chamberlain (1965). Results from a first study related to this population indicated that the population can easily be used as a bedding plant, and for large-scale plantations in particular, and that it has the potential for improvement as a cutflower crop (Karaguzel et al., 2003). However, it was thought that plant height in the population may be too high for use in some bedding plant designs such as formal planting design with annuals in restricted areas, and consequently, a reduction in plant height is needed without detrimentally affecting flowering characteristics. Breeding the plant for this purpose ought to be the primary goal of a long-term study, and previous studies indicated that paclobutrazol, a growth retardant of the triazole class, could be effective in reducing plant height in several species without decreasing flowering quality (Davis et al., 1988; Karaguzel and Ortacesme, 2002; Larson, 1985).

Also, paclobutrazol, can significantly accelerate flowering at certain doses in several woody, perennial and annual plants, such as Bouwardia longiflora H.B.\& K. (Wilkinson and Richards, 1987), Bougainvillea glabra Choisy (Karaguzel and Ortacesme, 2002), Pelargonium zonale L. (Nasr, 1995), Pelargonium $\times$ hortorum L.H. Bailey (Cox, 1991), Cosmos bipinnatus Cav. (Mohd et al., 1988) and Zinnia elegans Jacq. (Chen et al., 1993). The effectiveness of paclobutrazol can vary due to the method and site of application (Barrett and Bartuska, 1982), and it can be more effective and persistent on plant growth when applied as a soil or media drench (Karaguzel,
1999; Keever and Cox, 1989) because it is relatively immobile in soil, and easily taken up via roots and acropetally translocation (Davis et al., 1988; Davis and Andersen, 1989). However, there is limited scientific information on the effect of paclobutrazol on the growth and flowering of annual species of the Lupinus genus. This study was therefore conducted to determine the effects of the method of application and varied doses of paclobutrazol on the growth and flowering characteristics of a selected population of Lupinus varius native to South Anatolia.

\section{Materials and Methods}

Plant material. In this study, a selected population of Lupinus varius native to South Anatolia (Karaguzel et al., 2003) was used as plant material. Seeds (matured pods) were harvested in July 1998 from plants grown in a field plot at the Research and Application Station of Faculty of Agriculture, Akdeniz University, Antalya (Turkey) ( $36^{\circ} 53^{\prime} \mathrm{N}, 30^{\circ}$ $42^{\prime}$ E). Nonstandard seeds were discarded in the laboratory and the selected seed lot (seed weight $5.75 \pm 0.25 \mathrm{~g}$ ) was dusted with $3 \alpha, 4,7,7 \alpha$-tetrahydro-2[(trichlor methyl) thio]-1H-isoindole-1,3(2H)-dione (captan; Orthocide75; Koruma Tarim Inc., Izmit, Turkey) and stored at room temperature $(24.3 \pm$ $\left.4.3{ }^{\circ} \mathrm{C}\right)$ and relative humidity $(63.8 \pm 6.7 \%)$ until sowing. The experiment was performed between December 1998 and May 1999.

Sowing and growing conditions. Seeds were sown in 3-L (18-cm) pots on 17 Dec. 1998. One day before sowing, the seeds were mechanically scarified in the laboratory to counter the impermeable seed coat induced by dormancy by cutting seedcoats with the scissors on the opposite side of the hilum without causing any damage to the cotyledons. All pots were filled with a mixture consisting of 2 peat (Klasmann culture substrate, Klasmann and Deilmann $\mathrm{GmbH}, \mathrm{Linz}): 1$ river sand ( $\leq 2 \mathrm{~mm}$ in diameter) by volume. Soil obtained from the site of natural plant populations was also added at a rate of 5 $\mathrm{L} \cdot \mathrm{m}^{-3}$ of mixture to provide natural Rhizobium or Bradyrhizobium inoculation. Before sowing, three holes were made into the mixture of each pot, with each hole being about $2 \mathrm{~cm}$ in depth and equidistant to the other holes and the sides of the pot, and a seed was sown in each hole. The pots were then placed in an unheated greenhouse under natural photoperiod and light conditions. Monthly means of daily photosynthetically active radiation (PAR) (400 to 700 $\mathrm{nm}$ ) in greenhouse were 4.36, 5.03, 7.53, 9.92, 13.64 , and $16.82 \mathrm{~mol} \cdot \mathrm{m}^{-2} \cdot \mathrm{d}^{-1}$ in December, January, February, March, April, and May, respectively. Monthly average minimum/maximum greenhouse temperatures in December, January, February, March, April, and May were $6.7 / 27.4{ }^{\circ} \mathrm{C}, 7.0 / 26.2{ }^{\circ} \mathrm{C}, 6.3 / 25.2{ }^{\circ} \mathrm{C}$, 8.6/28.0 ${ }^{\circ} \mathrm{C}, 11.4 / 29.6^{\circ} \mathrm{C}$ and $16.6 / 30.2{ }^{\circ} \mathrm{C}$, respectively. The pots were hand-watered as needed, and two fertilizer programs were used during the growing period. Starting 1 month after sowing (at two- to three-leaf stage), N at $40 \mathrm{mg} \cdot \mathrm{L}^{-1}$ of $13 \mathrm{~N}-40 \mathrm{P}-13 \mathrm{~K}$ with minor elements (GroGreen Co., Rumst, Belgium) 
were applied twice a week every 2 weeks. In the remaining 4 months growing period, $\mathrm{N}$ at $50 \mathrm{mg} \cdot \mathrm{L}^{-1}$ as $18 \mathrm{~N}-18 \mathrm{P}-18 \mathrm{~K}$ with minor elements (GroGreen Co., Rumst, Belgium) were given to pots in the same interval, and was administered until main inflorescences flowered. In each fertilization program, 200 $\mathrm{mL}$ of fertilizer solution per pot was used for each time.

Paclobutrazol applications. When 5\% of the plants had elongated first internodes, 240 pots, each with three plants at seven- to eightleaf stage, were chosen and randomly grouped into three blocks each consisting of eight plots, with each plot comprising 10 pots (30 plants) that were placed to an adequate distance from other plots to keep it safe from active ingredient dispersion. On 25 Mar., paclobutrazol at doses of 0 (control), 0.625, 1.250, and 2.500 $\mathrm{mg}$ a.i./plant was applied to plants as a foliar spray or medium drench. These doses were obtained by diluting a concentrated suspension of paclobutrazol (Cultar $250 \mathrm{~g} \cdot \mathrm{L}^{-1} \mathrm{SC}$; Syngenta Izmir, Turkey) according to its studied levels and application methods. In foliar spray treatments, $5 \mathrm{~mL}$ of solutions at 125,250 and 500 $\mathrm{mg} \cdot \mathrm{L}^{-1}$ per plant were applied with minimal runoff, and control plants were sprayed with an equal amount with tap water. To provide the same doses in medium drench treatments, $1.875,3.750$, and $7.500 \mathrm{mg}$ active ingredient in $200 \mathrm{~mL}$ water were applied to 3-L media (pots) in which three plants were grown on a dose regime of $0.625,1.250$ and $2.500 \mathrm{mg}$ a.i./ plant, respectively. Similarly, equal amounts of tap water were applied to pots assigned as controls for media drench treatments. In the experiment, the $2 \times 4$ factorial treatment combinations (two application methods $x$ four doses) were distributed in a randomized complete-block design with three 10-pot (30plant) replications per treatment.

Data collection. Plant heights were measured from 5 Mar. to 23 Apr. in every $7 \mathrm{~d}$, and flowering percentages were calculated from 1 Apr. to 21 Apr. in every 5 d. Days to flower (first flower whorls open on the main inflorescences at $50 \%$ of plants) were estimated relative to sowing date. In all of 30 plants used for each replicate on 10 pots, plant height at flowering (height from soil to top of plant), stem diameter (10 $\mathrm{cm}$ above the soil), stem internode lengths (lengths from four internodes $10 \mathrm{~cm}$ below the point where the main inflorescence occurs) was measured on the dates when flowers on the main inflorescence were fully opened. At the same growth stage, measurements on length (length from connecting point of inflorescence to stem, to the top of inflorescence), diameter (3 $\mathrm{cm}$ under the first flower whorl) and internode lengths (in the lower three internodes) were made and flower number was counted in the main inflorescences. When all flowers of the inflorescences on the first three branches opened, branch number was counted and branch lengths (from arisen points of the branches from main stems to the top of inflorescence of the first three branches) were measured. Data were also gathered on branch inflorescence length, diameter, internode length, and flower number as being described for main inflorescences.
Data analysis. Data on the changes in the plant height and flowering percentage were plotted with standard error of three 30-plant replications using Microsoft Excel software. The remaining data relating to the characteristics considered in this study were tested by analysis of variance (ANOVA) using the SAS General Linear Model (SAS Institute, Cary, N.C.), and means were separated with Duncan's multiple range tests or trend analysis where appropriate.

\section{Results and Discussion}

Data presented on Fig. 1 show that the retarding effect of paclobutrazol on plant height could be seen $7 \mathrm{~d}$ after applications (in measurements on 2 Apr.) in all paclobutrazol doses applied as either a foliar spray or media drench. Two weeks after applications, significant differences were observed in plant height between application methods, and also doses used. Although increased paclobutrazol doses resulted in significant reduction rate increases in plant heights in each application method, plants treated with paclobutrazol as a

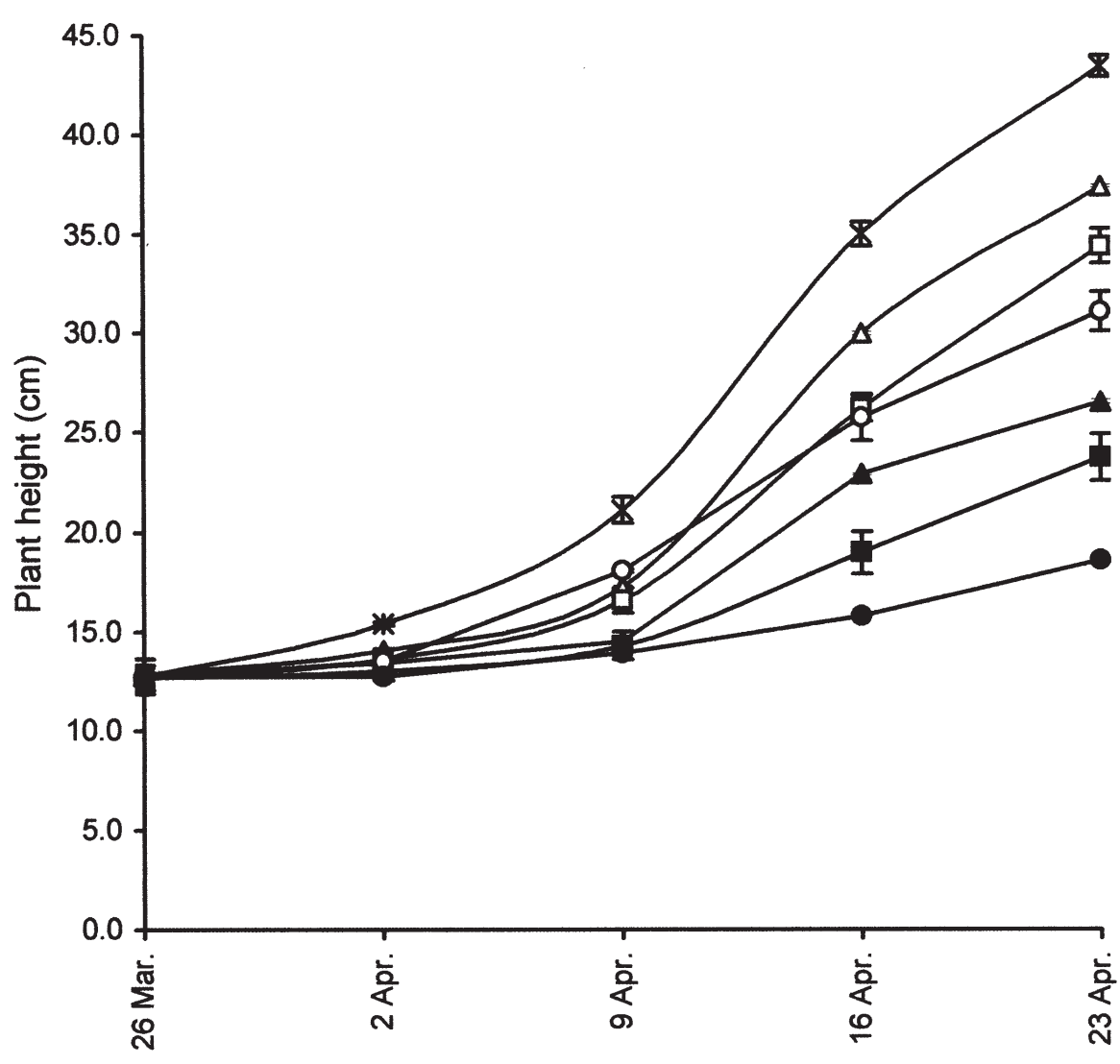

Measurement date

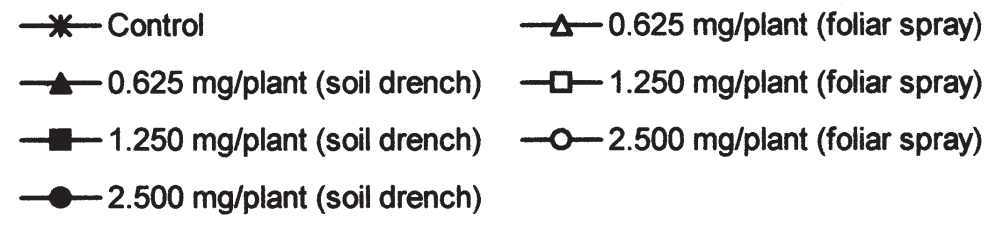

Fig. 1. Effects of paclobutrazol and application method on plant height of Lupinus varius during growing period. Data are means of three 10-pot (30-plant) replications and vertical bars indicate standard error of means when larger than the symbol. media drench continued to grow more slowly throughout the experimental period relative to control plants or plants treated with the same doses as a foliar spray (Fig. 1). The earliest flowering was observed in plants treated with paclobutrazol at $0.625 \mathrm{mg}$ a.i./plant dose as a foliar spray (Fig. 2). In plants treated with paclobutrazol at 1.250 and $2.500 \mathrm{mg}$ a.i./plant as foliar spray and 0.625 and $1.250 \mathrm{mg}$ a.i./plant as soil drench, flowering was slightly earlier than control plants. However control plants reached a $100 \%$ flowering level at the same time (on 21 Apr.) as foliar-sprayed plants. The latest flowering was recorded in plant treated paclobutrazol at $2.500 \mathrm{mg}$ a.i./plant as a soil drench and flowering percentages on $21 \mathrm{Apr}$. were still $<97.0 \%, 73.0 \%$, and $54.0 \%$ in media drench treated plants with paclobutrazol at $0.625,1.250$, and $2.500 \mathrm{mg}$ a.i./plant as a soil drench, respectively (Fig. 2).

The ANOVA results showed significant effects induced by application method, dose or application method $x$ dose interaction on the plant growth and main inflorescence characteristics of Lupinus varius (Table 1). Plants treated with different doses of paclobutrazol as 

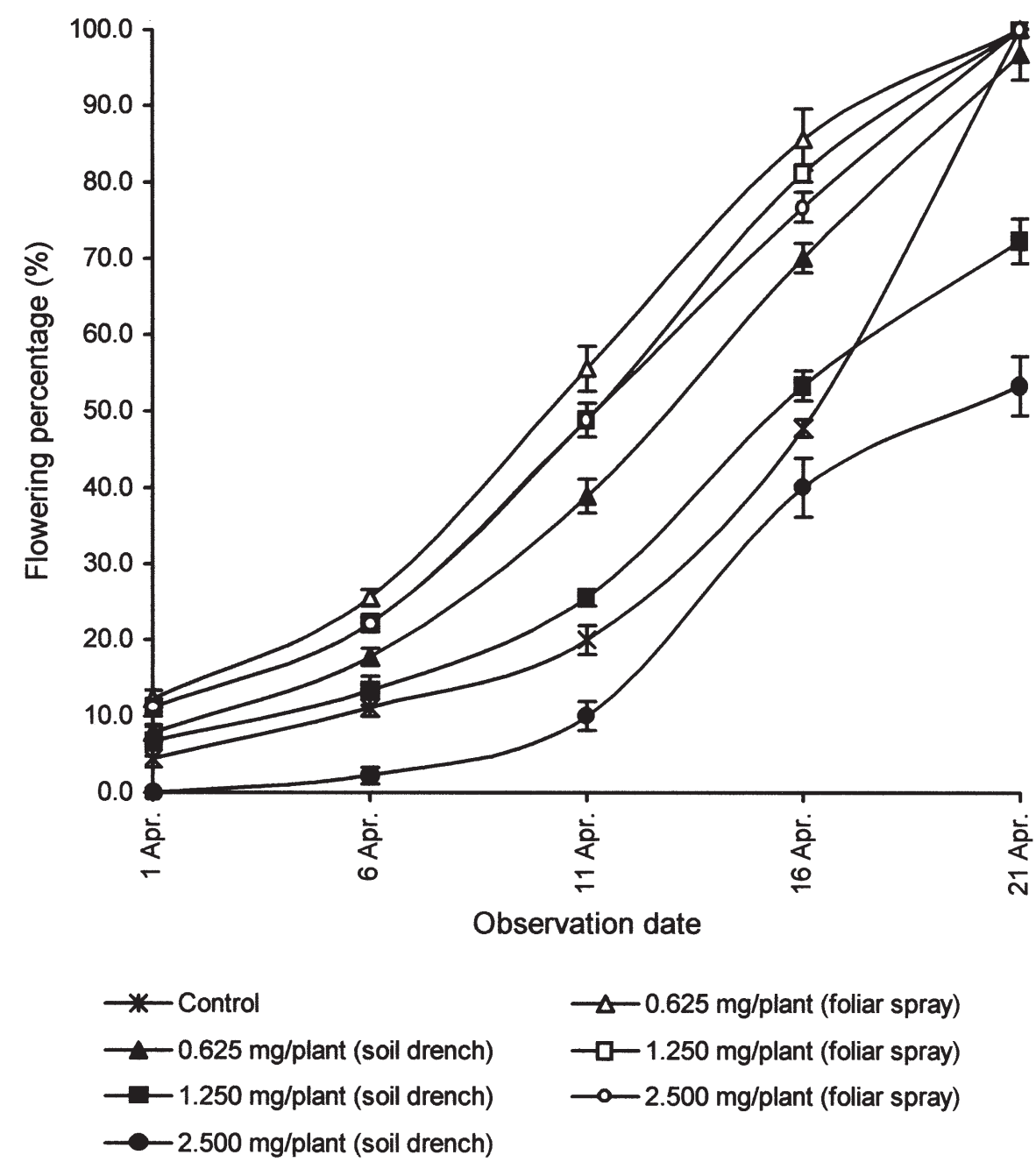

Fig. 2. Effects of paclobutrazol and application method on flowering percentage of Lupinus varius during flowering period. Data are means of three 10-pot (30-plant) replications and vertical bars indicate standard error of means when larger than the symbol.

a foliar spray flowered earlier than the media drench treated plants (Table 2). There were significant differences between doses applied as foliar spray or media drench. In each application method, a decrease in the days to flowering was recorded for the first paclobutrazol dose (0.625 mg a.i./plant) compared to other doses in general. However, increasing doses had no additional shortening effect on days to flowering in foliar spray treatments, but the highest dose of media drench delayed flowering when

\section{$\triangle-0.625 \mathrm{mg} / \mathrm{plant}$ (foliar spray) \\ $-\square-1.250 \mathrm{mg} / \mathrm{plant}$ (foliar spray) \\ $\multimap-2.500 \mathrm{mg} / \mathrm{plant}$ (foliar spray)}

玄
ingredient per plant compared to media drench applications were required to obtain a similar retarding effect on plant growth characteristics (Table 2).

Application method and application method $x$ dose interaction had no significant effect on plant stem diameter, while significant differences in plant stem diameter were only observed between treatments involving different doses of paclobutrazol (Table 1). In each application method, stem diameters increased linearly and quadratically with increasing doses (Table 2). Main inflorescence diameter increased in a quadratic manner, with similar rates between application methods with increasing doses, while only for the $0.625 \mathrm{mg}$ a.i./plant dose main inflorescence diameter was significantly higher in media drench applications than in foliar spray treatments (Table 2).

With an increase in the dose of paclobutrazol, flower numbers on main inflorescences increased linearly and quadratically in foliar sprays and quadratically in soil drench treatments (Table 2). However, the highest flower numbers were obtained with $1.250 \mathrm{mg}$ a.i./plant

Table 1. Mean squares from analysis of variance for the effect of application method and dose of paclobutrazol on the growth and main inflorescence characteristics of Lupinus varius.

\begin{tabular}{|c|c|c|c|c|c|c|c|c|c|}
\hline \multirow[b]{3}{*}{$\begin{array}{l}\text { Source of } \\
\text { variation }\end{array}$} & \multirow[b]{3}{*}{$\mathrm{df}$} & \multicolumn{8}{|c|}{ Mean square } \\
\hline & & \multicolumn{4}{|c|}{ Plant } & \multicolumn{4}{|c|}{ Main inflorescence } \\
\hline & & $\begin{array}{l}\text { Days to } \\
\text { flower }\end{array}$ & $\begin{array}{l}\mathrm{Ht} \\
(\mathrm{cm})\end{array}$ & $\begin{array}{c}\text { Stem } \\
\text { internode } \\
\text { length } \\
(\mathrm{cm})\end{array}$ & $\begin{array}{l}\text { Stem } \\
\text { diam } \\
(\mathrm{mm})\end{array}$ & $\begin{array}{l}\text { Length } \\
(\mathrm{cm})\end{array}$ & $\begin{array}{l}\text { Internode } \\
\text { length } \\
\text { (cm) }\end{array}$ & $\begin{array}{l}\text { Diam } \\
(\mathrm{mm})\end{array}$ & $\begin{array}{c}\text { Flowers } \\
\text { (no.) }\end{array}$ \\
\hline Replication & 2 & $0.125^{\mathrm{NS}}$ & $1.37^{\mathrm{NS}}$ & $0.019^{\mathrm{NS}}$ & $0.025^{\mathrm{NS}}$ & $0.058^{\mathrm{NS}}$ & $0.034^{\mathrm{NS}}$ & $0.001^{\mathrm{NS}}$ & $1.635^{\mathrm{NS}}$ \\
\hline Application method & 1 & $66.667^{* * *}$ & $368.715^{* * *}$ & $3.132^{* * *}$ & $0.079^{\mathrm{NS}}$ & $96.120^{* * * *}$ & $3.025^{* * *}$ & $0.140^{*}$ & $8.520 *$ \\
\hline Dose & 3 & $47.556^{* * *}$ & $407.517^{* * * *}$ & $3.045^{* * * *}$ & $0.739^{*}$ & $76.835^{* * *}$ & $2.578^{* * * *}$ & $0.281^{* * *}$ & $16.508^{* * * *}$ \\
\hline Total & 23 & & & & & & & & \\
\hline
\end{tabular}


Table 2. Influence of application method and dose of paclobutrazol on the growth and main inflorescence characteristics of Lupinus varius.

\begin{tabular}{|c|c|c|c|c|c|}
\hline \multirow{2}{*}{$\begin{array}{l}\text { Characteristic and } \\
\text { application method }\end{array}$} & \multicolumn{4}{|c|}{ Dose (mg a.i./plant) } & \multirow[b]{2}{*}{ Significance $^{\mathrm{z}}$} \\
\hline & Control & 0.625 & 1.250 & 2.500 & \\
\hline \multicolumn{6}{|l|}{ Days to flower } \\
\hline Foliar spray & $122.3 \mathrm{a}^{\mathrm{y}}$ & $114.7 \mathrm{a}$ & $117.3 \mathrm{a}$ & $117.0 \mathrm{~b}$ & Q \\
\hline Media drench & $122.0 \mathrm{a}$ & $117.0 \mathrm{a}$ & $120.3 \mathrm{a}$ & $125.3 \mathrm{a}$ & Q \\
\hline \multicolumn{6}{|l|}{ Plant height $(\mathrm{cm})$} \\
\hline Foliar spray & $43.3 \mathrm{a}$ & $37.3 \mathrm{a}$ & $34.2 \mathrm{a}$ & $29.0 \mathrm{a}$ & $\mathrm{L}, \mathrm{Q}$ \\
\hline Media drench & $43.2 \mathrm{a}$ & $27.1 \mathrm{~b}$ & $23.7 \mathrm{~b}$ & $18.6 \mathrm{~b}$ & $\mathrm{~L}, \mathrm{Q}$ \\
\hline \multicolumn{6}{|l|}{ Internode length $(\mathrm{cm})$} \\
\hline Foliar spray & $3.0 \mathrm{a}$ & $2.5 \mathrm{a}$ & $2.1 \mathrm{a}$ & $1.7 \mathrm{a}$ & $\mathrm{L}, \mathrm{Q}$ \\
\hline Media drench & $2.9 \mathrm{a}$ & $1.4 \mathrm{~b}$ & $1.1 \mathrm{~b}$ & $0.9 \mathrm{~b}$ & $\mathrm{~L}, \mathrm{Q}$ \\
\hline \multicolumn{6}{|l|}{ Stem diameter (mm) } \\
\hline Foliar spray & $5.4 \mathrm{a}$ & $5.8 \mathrm{a}$ & $6.0 \mathrm{a}$ & $6.4 \mathrm{a}$ & $\mathrm{L}, \mathrm{Q}$ \\
\hline Media drench & $5.4 \mathrm{a}$ & $5.7 \mathrm{a}$ & $6.1 \mathrm{a}$ & $6.1 \mathrm{a}$ & $\mathrm{L}, \mathrm{Q}$ \\
\hline \multicolumn{6}{|c|}{ Inflorescence length $(\mathrm{cm})$} \\
\hline Foliar spray & $19.7 \mathrm{a}$ & $18.9 \mathrm{a}$ & $17.1 \mathrm{a}$ & $14.2 \mathrm{a}$ & $\mathrm{L}, \mathrm{Q}$ \\
\hline Media drench & $19.6 \mathrm{a}$ & $14.2 \mathrm{~b}$ & $12.3 \mathrm{~b}$ & $8.0 \mathrm{~b}$ & $\mathrm{~L}, \mathrm{Q}$ \\
\hline \multicolumn{6}{|c|}{ Inflorescence internode length $(\mathrm{cm})$} \\
\hline Foliar spray & $3.6 \mathrm{a}$ & $3.5 \mathrm{a}$ & $3.1 \mathrm{a}$ & $2.6 \mathrm{a}$ & $\mathrm{L}, \mathrm{Q}$ \\
\hline Media drench & $3.6 \mathrm{a}$ & $2.6 \mathrm{~b}$ & $2.2 \mathrm{~b}$ & $1.5 \mathrm{~b}$ & $\mathrm{~L}, \mathrm{Q}$ \\
\hline \multicolumn{6}{|c|}{ Inflorescence diameter (mm) } \\
\hline Foliar spray & $3.7 \mathrm{a}$ & $4.0 \mathrm{~b}$ & $4.2 \mathrm{a}$ & $4.1 \mathrm{a}$ & Q \\
\hline Media drench & $3.9 \mathrm{a}$ & $4.4 \mathrm{a}$ & $4.4 \mathrm{a}$ & $4.0 \mathrm{a}$ & $\mathrm{Q}$ \\
\hline \multicolumn{6}{|l|}{ Flower (no.) } \\
\hline Foliar spray & $23.9 \mathrm{a}$ & $26.2 \mathrm{a}$ & $28.6 \mathrm{a}$ & $27.7 \mathrm{a}$ & $\mathrm{L}, \mathrm{Q}$ \\
\hline Media drench & $23.8 \mathrm{a}$ & $27.4 \mathrm{a}$ & $26.8 \mathrm{a}$ & $23.5 \mathrm{~b}$ & Q \\
\hline
\end{tabular}

${ }^{2}$ Linear (L) or quadratic $(\mathrm{Q})$ response at $P \leq 0.05$.

${ }^{y}$ Within dose (column) and each characteristic, means followed by the same letter are not significantly different at the 5\% level according to Duncan's multiple range test.

paclobutrazol in foliar spray applications, and with 0.625 and $1.250 \mathrm{mg}$ a.i./plant doses for media drench treatments.

The results relating to plant growth and main inflorescence characteristics indicated that paclobutrazol was more effective on most of the growth and flowering parameters when applied as a media drench in agreement with Davis et al. (1988). Barrett and Bartuska(1982) determined that leaf application of paclobutrazol was less effective in controlling stem elongation than stem or whole shoot applications in Phaseolus vulgaris L. and chrysanthemums. In our study, foliar spray treatments were made as wholeplant sprays with minimal runoff. However, plants treated with a foliar spray had more little stem surface than that of mature leaves depending on the plant architecture of Lupinus varius at the growth stage where paclobutrazol treatments were applied. Other studies have reported similar findings. Cox and Whittington (1988) found that the drench applications of paclobutrazol resulted in greater height reduction than the spray applications in Pilea cadierei Gagnep. \& Guillaumin. Keever et al. (1990) stated that drench had a greater effect than spraying in retarding the growth of woody landscape plants, such as Euonymus japonica Thunb. and Ilex crenata Thunb. 'Compacta'. Similar results were reported for Bougainvillea spectabilis Willd. (Karaguzel, 1999).

Previous studies also indicated that the effects of paclobutrazol on flower number could vary with plant species, dose and method of application. Wilkinson and Richards (1988) found that spray treatments increased, and drench treatments reduced, the total number of open flowers in Camellia $\times$ williamsii W.W. Sn. Matsoukis et al. (2001) reported that the number of flowers per plant increased to a maximum as drenched paclobutrazol concentration increased to $80 \mathrm{mg} \cdot \mathrm{L}^{-1}$, but higher concentrations resulted in a decrease in the number of flowers per plant in Lantana camara L. subsp. camara.

Branch growth and branch inflorescence characteristics are also important in determining ornamental value for Lupinus varius. The ANOVA results also indicated that application method, dose and application method $x$ dose interaction had significant effects on the branch growth and branch inflorescence characteristics of Lupinus varius (Table 3 ). In each application method, branch numbers linearly and quadrati- cally decreased with increasing the doses of paclobutrazol (Table 4). However, the number of branches per plant dramatically decreased at the lowest dose $(0.625 \mathrm{mg}$ a.i./plant $)$ of drenched-applied paclobutrazol with significant reduction afterwards, while a significant but slight decrease was recorded at $0.625 \mathrm{mg}$ a.i./plant dose in foliar spray treatments, and the number of branches per plant was constant at higher doses (1.250 and 2.500) (Table 4). Davis et al. (1988) showed that triazoles had little effect on shoot number per plant in some plants species, but in others shoot number was substantially reduced. Paclobutrazol applied as a soil drench retarded lateral shoot production in Plectranthus australis R. Br. (Wang and Blessington, 1990) and increased lateral shoot numbers in Gardenia jasminoides Ellis (De Baerdemaeker et al., 1994). Hamid and Williams (1997) treated Swainsona formosa (G. Don) J. Thomson plants with ancymidol, chlormequat, daminozide, flurprimidol and paclobutrazol, with results showing that paclobutrazol at $10 \mathrm{mg}$ a.i./plant consistently produced a compact pot plant with more lateral shoots. Application of paclobutrazol either as a media drench or foliar spray resulted in an increase in the number of lateral shoots per plant in Bougainvillea spectabilis (Karaguzel, 1999), but spray treatments increased and media drenches reduced lateral shoot number production in Bougainvillea glabra 'Sanderiana' (Karaguzel and Ortacesme, 2002).

In each application method, branch length decreased linearly and quadratically with increasing doses, but media drench treatments were found to be more effective in reducing branch length than foliar sprays as branch length in drench treated plants was shorter than foliar treated plants at the same doses (Table 4).

Application method, dose of paclobutrazol and interaction between these factors had significant effects on the length of branch inflorescences and branch inflorescence internodes of Lupinus varius. For each parameter, length decreased linearly and quadratically with increasing doses of paclobutrazol. However, drench applications were more effective than foliar sprays in reducing branch inflorescence and branch inflorescence internode lengths at the same doses, as in the case of the main inflorescences (Table 4). Additionally, the responses of branch inflorescence diameter to application method and dose of paclobutrazol were similar to those recorded for the main inflorescences. Branch inflorescence diameters

Table 3. Mean squares from analysis of variance for the effect of application method and dose of paclobutrazol on the branch growth and branch inflorescence characteristics of Lupinus varius.

\begin{tabular}{|c|c|c|c|c|c|c|c|}
\hline \multirow[b]{3}{*}{$\begin{array}{l}\text { Source of } \\
\text { variation }\end{array}$} & \multirow[b]{3}{*}{ df } & \multicolumn{6}{|c|}{ Mean square } \\
\hline & & \multicolumn{2}{|c|}{ Branch } & \multicolumn{4}{|c|}{ Branch inflorescence } \\
\hline & & No. & $\begin{array}{l}\text { Length } \\
(\mathrm{cm})\end{array}$ & $\begin{array}{l}\text { Length } \\
\text { (cm) }\end{array}$ & $\begin{array}{c}\text { Internode } \\
\text { length }(\mathrm{cm})\end{array}$ & $\begin{array}{l}\text { Diam } \\
(\mathrm{mm})\end{array}$ & $\begin{array}{l}\text { Flowers } \\
\text { (no.) }\end{array}$ \\
\hline Replication & 2 & $0.017^{\mathrm{NS}}$ & $2.399^{*}$ & $0.485^{\mathrm{NS}}$ & $0.031^{\mathrm{NS}}$ & $0.001^{\mathrm{NS}}$ & $0.993^{\mathrm{NS}}$ \\
\hline Application method & 1 & $6.773^{* * *}$ & $209.864^{* * * *}$ & $93.063^{* * *}$ & $3.627^{* * * *}$ & $0.088^{*}$ & $43.148^{* * * *}$ \\
\hline Dose & 3 & $3.385^{* * * *}$ & $141.755^{* * *}$ & $39.026^{* * * *}$ & $2.212^{* * * *}$ & $0.168^{* * * *}$ & $7.624^{* * *}$ \\
\hline Application method $\times$ dose & 3 & $1.212^{* * * *}$ & $26.149^{* * *}$ & $11.613^{* * *}$ & $0.532^{* * * *}$ & $0.023^{\mathrm{NS}}$ & $19.970^{* * * *}$ \\
\hline Error & 14 & 0.006 & 0.469 & 0.162 & 0.012 & 0.012 & 0.854 \\
\hline Total & 23 & & & & & & \\
\hline
\end{tabular}

NS,*,*******Nonsignificant or significant at $P<0.05,0.01$ and 0.001 , respectively. 
Table 4. Influence of application method and dose of paclobutrazol on branch growth and branch inflorescence characteristics of Lupinus varius.

\begin{tabular}{|c|c|c|c|c|c|}
\hline \multirow{2}{*}{$\begin{array}{l}\text { Characteristic and } \\
\text { application method }\end{array}$} & \multicolumn{4}{|c|}{ Dose (mg a.i./plant) } & \multirow[b]{2}{*}{ Significance } \\
\hline & Control & 0.625 & 1.250 & 2.500 & \\
\hline \multicolumn{6}{|l|}{ Branch number (no.) } \\
\hline Foliar spray & $2.9 \mathrm{a}^{\mathrm{y}}$ & $2.6 \mathrm{a}$ & $2.3 \mathrm{a}$ & $2.3 \mathrm{a}$ & $\mathrm{L}, \mathrm{Q}$ \\
\hline Media drench & $3.0 \mathrm{a}$ & $1.8 \mathrm{~b}$ & $0.6 \mathrm{~b}$ & $0.4 \mathrm{~b}$ & $\mathrm{~L}, \mathrm{Q}$ \\
\hline \multicolumn{6}{|l|}{ Branch length $(\mathrm{cm})$} \\
\hline Foliar spray & $25.1 \mathrm{a}$ & $22.7 \mathrm{a}$ & $20.5 \mathrm{a}$ & $18.6 \mathrm{a}$ & $\mathrm{L}, \mathrm{Q}$ \\
\hline Media drench & $25.0 \mathrm{a}$ & $17.0 \mathrm{~b}$ & $12.2 \mathrm{~b}$ & $9.1 \mathrm{~b}$ & $\mathrm{~L}, \mathrm{Q}$ \\
\hline \multicolumn{6}{|c|}{ Inflorescence length (cm) } \\
\hline Foliar spray & $14.1 \mathrm{a}$ & $13.5 \mathrm{a}$ & $12.9 \mathrm{a}$ & $11.0 \mathrm{a}$ & $\mathrm{L}, \mathrm{Q}$ \\
\hline Media drench & $14.3 \mathrm{a}$ & $8.6 \mathrm{~b}$ & $7.6 \mathrm{~b}$ & $5.2 \mathrm{~b}$ & $\mathrm{~L}, \mathrm{Q}$ \\
\hline \multicolumn{6}{|c|}{ Inflorescence internode length (mm) } \\
\hline Foliar spray & $3.3 \mathrm{a}$ & $3.0 \mathrm{a}$ & $2.9 \mathrm{a}$ & $2.6 \mathrm{a}$ & $\mathrm{L}, \mathrm{Q}$ \\
\hline Media drench & $3.3 \mathrm{a}$ & $2.4 \mathrm{~b}$ & $1.8 \mathrm{~b}$ & $1.2 \mathrm{~b}$ & $\mathrm{~L}, \mathrm{Q}$ \\
\hline \multicolumn{6}{|c|}{ Inflorescence diameter $(\mathrm{mm})$} \\
\hline Foliar spray & $2.9 \mathrm{a}$ & $3.1 \mathrm{a}$ & $3.3 \mathrm{a}$ & $3.2 \mathrm{a}$ & Q \\
\hline Media drench & $3.0 \mathrm{a}$ & $3.4 \mathrm{a}$ & $3.5 \mathrm{a}$ & $3.1 \mathrm{a}$ & Q \\
\hline \multicolumn{6}{|l|}{ Flower (no.) } \\
\hline Foliar spray & $18.7 \mathrm{a}$ & $20.4 \mathrm{a}$ & $22.3 \mathrm{a}$ & $21.6 \mathrm{a}$ & $\mathrm{L}, \mathrm{Q}$ \\
\hline Media drench & $18.6 \mathrm{a}$ & $21.4 \mathrm{a}$ & $16.9 \mathrm{~b}$ & $15.3 \mathrm{~b}$ & $\mathrm{~L}, \mathrm{Q}$ \\
\hline
\end{tabular}

${ }^{2}$ Linear $(\mathrm{L})$ or quadratic $(\mathrm{Q})$ response at $P \leq 0.05$.

${ }^{y}$ Within dose (column) and each characteristic, means followed by the same letter are not significantly different at the $5 \%$ level according to Duncan's multiple range test.

increased in a quadratic manner with increasing doses of paclobutrazol, without being significant differences between application methods (Table 4).

In foliar spray treatments, number of flowers on branch inflorescences significantly increased with increasing doses, in comparison to control treatments. In contrast, the doses of paclobutrazol at 1.250 and $2.500 \mathrm{mg}$ a.i./plant resulted in significant decreases in the number of flowers per branch inflorescence when applied as a media drench, and a significant increase in flower number in media drench treatments was only recorded for the 0.625 mg a.i./plant dose (Table 4). These responses to application method and dose were quite different from that of the main inflorescences. Furthermore, there were significant differences in reductions in growth characteristics of main and branch inflorescences due to the method of application of paclobutrazol. While the application of paclobutrazol at $2.500 \mathrm{mg}$ a.i./plant (100\% reduction) (Table 2 ) as a foliar spray resulted in reductions in the lengths of the main inflorescence and main inflorescence internode of $27.9 \%$ and $27.8 \%$ respectively, reductions in the same characteristics for branch inflorescences decreased to $22 \%$ and $21.2 \%$ respectively, at the same dose. In contrast, media drench applications of paclobutrazol at $2.500 \mathrm{mg}$ a.i./plant (100\% reduction) (Table 2) resulted in reductions in main inflorescence and main inflorescence internode lengths of $59.2 \%$ and $58.3 \%$ respectively, but reduction rates increased to $63.6 \%$ in branch inflorescence and branch inflorescence internode length (Table 2, Table 4). These results highlight that paclobutrazol has highly retarding effects on growth and flowering characteristics of Lupinus varius when applied as a media drench. This different response is possibly due to the restricted absorption of paclobutrazol into plants via leaves and to the relatively short time of availability in foliar spray treatments, in contrast to likely increasing and persistent effects of paclobutrazol taken up by roots and translocated to growing points of the plant during the entire growing period.

In conclusion, the results presented in this study indicated that the application of paclobutrazol slightly decreases the time to flowering of Lupinus varius plants, especially when applied as a foliar spray. Media drench applications are more effective than foliar spray treatments in reducing growth for most of the plant parameters studied, and foliar sprays with about 4-fold amount of active ingredient were required to produce growth retarding effects equaled to observed for media drench applications. However, a noticeable decrease in branch number at $0.625 \mathrm{mg}$ a.i./plant dose, and reductions of flower numbers, in general, on the main and branch inflorescences at higher doses (1.250 and $2.500 \mathrm{mg}$ a.i./plant) in media drench applications result in a decrease in ornamental value of Lupinus varius plants. Foliar sprays of paclobutrazol at 0.625 and $1.250 \mathrm{mg}$ a.i./plant can therefore be used to increase flower numbers and control partial excessive plant height without causing a decrease in flowering quality or ornamental value of Lupinus varius.

\section{Literature Cited}

Barrett, J.E. and C.A. Bartuska. 1982. PP333 effects on stem elongation dependent on site of application. HortScience 17:737-738.

Blamey, M. andC. Grey-Wilson. 1998. Mediterranean wild flowers. HarperCollins, London.

Brickell, C. and J.D. Zuk. 1997. ASHS A-Z encyclopedia of garden plants. In: C. Brickell and J.D. Zuk (eds.). DK Publ., New York.

Burnie, D. 2000. Wild flowers of the Mediterranean DK Publ., London.

Chamberlain, D.F. 1965. Lupinus, p. 38-40. In: P.H. Davis (ed.). Flora of Turkey and the East Aegean Islands. vol 3. Edinburgh Univ., Edinburgh.

Chen, C.L., G.J. Keever, and C.F. Deneke. 1993. Growth and flowering of triazole-treated zinnia (Zinnia elegans) and marigold (Tagetes erecta). Plant Growth Regulat. Soc. Amer. Qrtly. 21:169-179.

Cox, D.A. 1991. Gibberellic acid reverses effects of excess paclobutrazol on geranium. HortScience
26:39-40.

Cox, D.A. and F.F. Whittington. 1988. Effects of paclobutrazol on height and performance of aluminum plant in simulated interior environment. HortScience 23:222.

Davis, T.D. and A.S. Andersen. 1989. Growth retardants as aids in adapting new floricultural crops to pot culture. Acta Hort. 252:77-85.

Davis, D.T., G.L. Steffens, and N. Sankhla. 1988. Triazole plant growth regulators, p. 63-105. In: J. Janick (ed.). Horticultural reviews. vol. 10. Timber Press, Portland, Ore.

De Baedemaeker, C.I., J.M. Van Huylenbroeck, and P.C. Debergh. 1994. Influence of paclobutrazol and photoperiod on growth and flowering of Gardenia jasminoides Ellis cultivar 'Wetchii'. Scientia Hort. 58:315-324.

Ecker, R.,A. Barzilay, L. Afgin, and A.A. Watad. 1992. Growth and flowering responses of Matthiola incana $\mathrm{L}$. R. Br. to paclobutrazol. HortScience 27:1330.

Hamid, M.M. and R.R. Williams. 1997. Effect of different types and concentrations of plant growth retardants on Sturt's desert pea (Swainsona formosa). Scientia Hort. 71:79-85.

Karaguzel, O., I. Baktir, S. Cakmakci, V. Ortacesme, B. Aydinoglu and M. Atik. 2003. Effects of growing conditions and sowing time on the growth and flowering characteristics of Lupinus varius (L.) native to South Anatolia. Akdeniz Univ. J. Fac. Agr. 16(2):187-197.

Karaguzel, O. and V. Ortacesme. 2002. Influence of paclobutrazol on the growth and flowering of Bougainvillea glabra 'Sanderiana'. Akdeniz Univ. J. Fac. Agr. 15(1):79-84.

Karaguzel, O. 1999. Effect of paclobutrazol on growth and flowering of Bougainvillea spectabilis Willd. Tr. J. Agr. For. 23:527-532.

Keever, G.J., W.J. Foster, and J.C. Stephenson. 1990. Paclobutrazol inhibits growth of woody landscape plants. J. Environ. Hort. 8(1):41-47.

Keever, G.J. and D.A. Cox. 1989. Growth inhibition in Marigold following drench and foliar-applied paclobutrazol. HortScience 24:390.

Larson, R.A. 1985. Growth regulators in floriculture, p. 410-481. In: J. Janick (ed.). Horticutural reviews. vol. 7. AVI Publ., Westport, Ct.

Matsoukis, A.S.,A. Chronopoulou-Sereli, I.D. Dimopoulos, and A. Kamoutsis. 2001. Response of Lantana camara L. subsp. camara to paclobutrazol and shading. Can. J. Plant Sci. 8:761-764.

Miller, A. and A.M. Armitage. 2002. Temperature, irradiance, photoperiod and growth retardants influence greenhouse production of Angelonia angustifolia Benth. Angel Mist Series. HortScience 37:319-321.

Mohd, A., S. Gauri, A.K. Muthoo, M. Ahmad and G. Shanker. 1988. Effect of paclobutrazol on growth and flowering of Cosmos (Cosmos bipinnatus). Punjab Hort. J. 28:105-108.

Nasr, M.N. 1995. Effects of methods of application and concentrations of paclobutrazol on Pelargonium zonale (L) as a pot plant. Alexandria J. Agr. Res. 40(3):261-279.

Stamps, R.H. and R.J.Henny. 1986. Paclobutrazol and night interruption lighting affect Episcia growth and flowering. HortScience 21:1005-1006.

Tayama, H.K. and S.A. Carver. 1990. Zonal geranium growth and flowering responses to six growth regulators. HortScience 25:82-83.

Wang,Y.T. and T.M. Blessington. 1990. Growth of four tropical foliage species treated with paclobutrazol or uniconazole. HortScience 25(2):202-204.

Wilkinson, R.I. and D. Richards. 1988. Influence of paclobutrazol on growth and flowering of Camellia $\times$ wiliamsii. HortScience 23:359-360.

Wilkinson-R.I. and D. Richards. 1987. Effects of paclobutrazol on growth and flowering of Bouvardia humboldtii. HortScience 22(3):444-445. 